\title{
Employment and wage premiums in South African manufacturing exporters: firm-level evidence
}

\author{
Corresponding author: \\ Carli Bezuidenhout \\ School of Economic Sciences and TRADE research entity, North-West University, \\ Potchefstroom, South Africa \\ Tel no: $+27(0) 182852321$ \\ E-mail: carli.bezuidenhout@nwu.ac.za
}

\author{
Co-author: \\ Marianne Matthee
}

Gordon Institute of Business Science (GIBS), University of Pretoria, Sandton, South Africa

Tel no: $+27(0) 114474227$

E-mail: Mattheem@gibs.co.za

Co-author:

Neil Rankin

Department of Economics, Stellenbosch University, South Africa

Tel no: $+27(0) 218082678$

E-mail: neilrankin@sun.ac.za

\section{Acknowledgements:}

All the authors would like to thank the United Nations University World Institute of Development Economics Research and National Treasury for funding support. Also, they would like to thank the South African Revenue Service for the data.

Finally, Marianne Matthee also acknowledges support from the National Research Foundation (NRF) of South Africa. Any opinion, finding and conclusion, or recommendation expressed in this material is that of the authors and the NRF does not accept any liability in this regard. 


\section{Abstract}

South Africa is currently suffering from high unemployment. As export activity is generally associated with higher economic growth, productivity, employment levels and wages, this papers investigates if increasing export activity is one of the solutions to the high unemployment levels in South Africa. By using newly made available administrative data on the population of South African firms, this paper aims to deepen the understanding of the wage premium, employment premium and employment growth of exporters relative to non-exporters (as well as within exporters). By following the methodology of Bernard and Jensen, the results show that South African manufacturing exporters do have an employment premium and wage premium. But advocating increased export activity is not enough, as exporting firms are heterogenous. Furthermore, employment growth of exporters (measured by estimating firstdifference regressions) is faster than non-exporters, but growth in jobs is skewed towards higher skilled, more experience workers.

\section{Keywords}

Employment premium, wage premium, employment growth, extensive margin, intensive margin, South African manufacturing exporters.

\section{JEL codes}

F10, F16 


\section{Introduction}

South Africa is a country that is plagued by economic malaise - most notably seen in the country's high unemployment rate $(27.2 \%$ in the second quarter of 2018$)$ and high youth unemployment rate (38.8\% for youth aged 15-24 years, in the second quarter of 2018) (Statistics South Africa, 2018). Internationally, exports have been identified as a key driver of growth that would help to reduce such malaise, as it can lead to employment creation (Rankin, 2013). Accordingly, South African policy makers also identified exports as a means to increase economic growth and decrease unemployment, as it is stated in the National Development Plan (2013:120) that 'Expanded and diversified exports can be expected to increase employment'. To understand whether increased exporting is a viable path for widespread employment creation, there is a need for an in-depth understanding about the relationship between exporting, labour demand and wages at a firm-level in South Africa.

Work has been done in the South African context to explore this relationship (see for example Rankin (2001), Edwards et al. (2008), Gumede \& Rasmussen (2002), Gumede (2004), Matthee \& Krugell (2012), Rankin (2013), Naughtin \& Rankin (2014) and Matthee et al. (2016a)). These studies on South African exporting firms show that exporters are larger and pay more and that a degree of heterogeneity is involved as size and wages paid differ by destination and the number of products exported, as well as whether firms are two-way traders (i.e. they import and export) (Rankin \& Schöer, 2013; Matthee et al., 2016b; Edwards et al., 2016).

The existing research on the linkages between exports, employment (in terms of both levels and growth) and wages in the South African however, has a number of limitations. The first is that existing work has relied on samples rather than the population of firms and workers and thus the existing results may be influenced by sampling procedures (see for example Rankin (2001), Edwards et al. (2008), Gumede \& Rasmussen (2002), Gumede (2004), Matthee \& Krugell (2012), Rankin (2013), Naughtin \& Rankin (2014) and Matthee et al. (2016a)). The second is that most of the results examine firm-level averages and do not link workers to firms. In the cases where they do, they use a sample of workers and often the sampling procedure for selecting the workers is not clear (see for example Edwards et al. (2008), Rankin \& Schöer (2008), Rankin \& Schöer (2013), Matthee \& Krugell (2012)). Lastly, many of the studies are now relatively outdated and may not reflect current labour market dynamics (see for example Rankin (2001), Edwards et al. (2008), Gumede \& Rasmussen (2002), Gumede (2004), Matthee \& Krugell (2012)). 
Recently, these limitations on using population data in the South African export literature has been addressed through Matthee et al. (2016b) and Edwards et al. (2016). These studies were among the first to use newly made available administrative data and illustrated the complexity that exists within the behaviour of South African manufacturing exporters. In particular, these studies showed that exporter heterogeneity in terms of whether they are two-way traders, the number of products they export, the number of destinations exported to and the type of destinations exported to all contribute to different levels of number of employees and wages.

This paper adds granularity to the findings of these studies in two ways. Firstly, it also uses the newly made available administrative data to broaden the literature through an in-depth investigation of the relationship between exporting, labour demand and wages (by taking all employees of manufacturing exporters into account). This is done by analysing the employment premium and the wage premium of South African exporters relative to nonexporters as well as within exporters (considering export destination, exporter dynamics (whether a firm entered, exited or continued in the export market), number of products exported and number of destinations served). Secondly, this paper is the first to investigate employment growth (change in the number of employees) in South African exporting firms by considering the employment of different types of employees in order to understand how exports adds to employment creation and subsequently contributes to decreasing high unemployment levels.

This paper does not explicitly deal with the direction of causality between exporting and outcomes since it is primarily descriptive in nature. However, there is a large literature on whether 'better' firms self-select into the export market or become 'better' through learningby-exporting which suggests that often both are present but that the relative importance differs by context (see, for example, Fernandes and Isgut, 2015; Cruz et al., 2016; Siba and Gebreeyesus, 2016). In our paper, it does seem that there may be some self-selection of 'better' performing firms into exporting given that wages are higher prior to entry but this issue needs to be tackled with more rigour in subsequent research. The rest of the paper is outlined as follows: section 2 discusses global trends in respect of employment premiums and wage premiums and employment growth in exporting firms, compared with non-exporting firms; section 3 looks at the results of some South African export studies on these issues; section 4 provides the empirical analysis underpinning the current study; and section 5 offers some key conclusions. 


\section{Employment and wage premiums of exporting firms: global trends}

The initial firm-level work of Bernard and Jensen (in the late 1990s) led to the development of the Melitz model of heterogeneous firms to explain the observed productivity-exporting relationship (Bernard \& Jensen, 1995; Bernard \& Jensen, 1999; Melitz, 2003). This pioneering research inspired a new series of micro-econometric studies on firm heterogeneity and productivity.

One stylised fact that emerged from these studies is that exporting firms (in both developed and developing countries) are more productive than their non-exporting counterparts. (See, for example, Delgado et al., 2002; Girma et al., 2004; Van Biesebroeck, 2005; Fariñas \& Martín-Marcos, 2007; Bernard et al., 2007; Sinani and Hobdari; 2010). The higher productivity of exporting firms relative to non-exporting firms can be linked to factors such as having a larger workforce (resulting in an employment premium and employment growth) and paying higher wages (resulting in a wage premium).

An export employment premium is created when an exporting firm employs (on average) more workers than non-exporters (Brambilla et al., 2015). For example, Van Biesebroeck (2005) showed that, after controlling for firm characteristics, exporters in nine sub-Saharan African countries employed about three times more workers than their domestic counterparts, giving rise to a $213 \%$ employment premium. Still in Africa, Bigsten et al. (2004) showed that exporters in Cameroon, Kenya, Ghana and Zimbabwe employed on average 342 workers, whereas nonexporters in these countries employed only 51 workers. The results of a later study by Rankin et al. (2006) revealed that exporters in Kenya, Ghana, Tanzania, South Africa and Nigeria employed on average 273 workers, compared with non-exporters' 67 workers. The Melitz model provides two theoretical mechanisms through which firm size and exporting are related. The first is that larger firms are better able to spread the fixed costs of entering individual export markets across existing production. The second is that these firms are large because they are more productive, and once they enter the export market they are able to expand production further (Melitz, 2003).

Accoring to Bernard and Jensen (1999) exporters employ more people, by creating proportionally more jobs, and therefore they experience more employment growth, relative to non-exporters. Moreover, such growth tends to be more rapid. According to Bernard and Jensen (1999), jobs at exporting firms are also more sustainable as these firms' survival rate is higher than that of non-exporters. 
A study on French manufacturing firms showed that it was large firms that contributed most to employment creation (Biscourp \& Kramarz, 2007). Turco and Maggioni (2013), in turn, found a positive relationship between the trade intensity and employment growth rates of manufacturing firms in Turkey. Furthermore, the pace of such employment growth is often quite impressive. For example, Rankin (2005) showed that African exporters in Ghana, Kenya and Tanzania realised a 56\% higher employment growth rate over an eight-year period.

The employment growth (stemmimg from demand for labour) evident in exporting firms is influenced by workers' skills levels (Brambilla et al., 2015). In the literature, workers are generally divided into blue collar (lower-skilled) jobs and white collar (higher-skilled) jobs (Klein et al., 2013). Isgut (2001) stated that for a firm to become competitive enough to succeed in exporting, its employees must attain certain technical and managerial skills. Because of the complex nature of exporting, which typically demands regular product and service upgrades, exporters tend to hire more skilled (white collar) workers (Bas, 2012; Brambilla et al., 2015). Similarly, when exporters expand their operations, they usually employ more highly skilled workers (Bernard \& Jensen, 1997).

These highly skilled workers usually earn a wage premium, also called a skills pemium. The skills premium is one of three possible reasons (identified by Brambilla et al. (2015)) why exporting firms pay higher wages. Exporters require more skilled workers because of the higher quality of products demanded by foreign buyers and the complexity of the export process. To attract and retain skilled workers, exporting firms need to pay them higher wages. The second reason exporters pay a wage premium is they are relatively more productive and thus generate higher profits than non-exporters, therefore they may share a proportion of their profits with the workforce ('productivity rent sharing') (Fafchamps, 2007). This leads to higher wages (Brambilla et al., 2010; Amiti \& Davis, 2012; Baumgarten, 2013). Finally the third reason why exporters pay higher wages exporters is they have to remain productive and competitive, therefore they need to keep pace with changes in technology. Investing in R\&D and keeping their production processes technologically fresh requires commensurate, higher-level skills (Aw et al., 2011).Schank et al. (2007) summarised the findings of a number of studies on the wage premium phenomenon in exporting firms, in which different wage variables were used, namely average wages, average labour cost and wages per employee. The wage premium in exporting firms in developing country studies was found to be particularly pronounced.

As exporting firms are heterogeneous, the wage premium varies from one exporting firm to the next (Bernard et al., 2009). For example, using US manufacturing data, Bernard et al. (2009) showed that there was a clear difference between firms that exported multiple products 
to multiple destinations, and firms that exported a single product to a single destination. The higher the numbers of products exported and destinations served, the higher the employment and wage levels were.

Another factor influencing the wage premum is the location of an export destination. A study on African exporters by Milner and Tandrayen (2007) found that the wage premium decreased when firms exported to non-African markets. The authors explained that non-African markets are more competitive and have fewer natural barriers, which have 'a disciplining effect on wage costs' (Milner \& Tandrayen, 2007:24).

\section{Firm-level findings from South African export studies}

The results of firm-level export studies in South Africa mirror the global trends outlined in section 2. Compared to non-exporters, South African exporters are larger (Edwards et al., 2008; Gumede \& Rasmussen, 2002; Gumede, 2004; Naughtin \& Rankin, 2014; Rankin, 2013), pay higher wages and are more productive (Matthee \& Krugell, 2012; Rankin, 2001; Rankin, 2013; Matthee et al., 2016a), and display a stronger demand for skilled workers (Rankin, 2001; Edwards et al., 2008; World Bank, 2014). Similarly, the way in which these characteristics are combined depends on the numbers of products exported and the destinations served (Rankin, 2001; Rankin \& Shoër, 2013; Rankin, 2013; Matthee et al., 2016b). For example, Rankin and Schoër (2013) identified a wage premium of about $17 \%$ among exporters to non-African markets, but there was no evidence of a wage premium among exporters serving the African market (specifically SADC). Rankin and Schöer (2013) also showed that exporters to nonAfrican markets had a skills premium, but exporters to other African countries did not. Matthee et al. (2016b) confirmed the findings of Rankin and Schöer (2013), indicating that the so-called 'non-African' exporters employed more workers and paid higher wages than 'African' exporters.

The existing research on the linkages between exports, employment (in terms of both levels and growth) and wages in the South African however, has a number of limitations. The first is that existing work has relied on samples rather than the population of firms and workers and thus the existing results may be influenced by sampling procedures (see for example Rankin (2001), Edwards et al. (2008), Gumede \& Rasmussen (2002), Gumede (2004), Matthee \& Krugell (2012), Rankin (2013), Naughtin \& Rankin (2014) and Matthee et al. (2016a)). The second is that most of the results examine firm-level averages and do not link workers to firms. In the cases where they do, they use a sample of workers and often the sampling procedure for selecting the workers is not clear (see for example Edwards et al. (2008), Rankin \& Schöer (2008), Rankin \& Schöer (2013), Matthee \& Krugell (2012)). Lastly, many of the studies are 
now relatively outdated and may not reflect current labour market dynamics (see for example Rankin (2001), Edwards et al. (2008), Gumede \& Rasmussen (2002), Gumede (2004), Matthee \& Krugell (2012)).

\section{Empirical analysis}

\subsection{Data used}

In order to investigate the employment premium, wage premium and employment growth of exporting firms in the manufacturing sector in South Africa, a panel dataset was created by combining three different administrative datasets collected by SARS: Company Income Tax (CIT) return data, Personal Income Tax (also known as Pay-As-You-Earn (PAYE), or IRP5) employee data and customs transactions data'.

The CIT data contains the balance sheet and income statements of firms from which variables describing firm characteristics can be obtained. Two shortcomings of the CIT data are that it has no variables for the number of employees in a firm or identifiers as to whether or not it is an exporter. Consequently, these variables were obtained from the IRP5 and customs data, respectively. All three datasets (CIT, IRP5 and customs data) were linked through a conjunction table (using firm-specific identifiers, as the data was anonymised) which was provided by SARS.

The IRP5 data (which was cleaned up to remove any duplication or errors) provides information on the period an individual has worked in a specific job, their income and age ${ }^{2}$. As the IRP5 data needed to match the firm-level CIT data, the IRP5 variables were collapsed onto the firm level. Three variables were obtained from the IRP5 data. First, a measure of firm size (number of employees) was created. To cater for differences in numbers of days worked, a weighted number of employees was calculated. Secondly, the age of employees was used to determine how many employees in a firm were younger and older than 30 , respectively. Thirdly, monthly income was used to determine the number of workers in a firm earning above and below R6500 per month. These three variables were merged onto the CIT data (using the conjunction table).

\footnotetext{
${ }^{1}$ It is important to note that a proportion of the data was lost when using the conjunction table to merge the CIT, IRP5 and customs data, therefore there is a possibility of selection bias in the data.

2 The IRP5 data was limited in terms of worker characteristics (no variables on race, education, skills and experience).
} 
The customs data ${ }^{3}$ reports South African firms' export transactions on a monthly basis and contains the following variables: trader id (firms), tariff code (HS6-digit level product code), country of destination (market), country of origin (SA), customs value of the transaction (in South African Rand) and the statistical value (number of units). From the transaction-level customs data, five types of variables were created (on a firm level) to link onto the CIT and IRP5 data: dummy variables indicating if a firm was an exporter (or not), the export destination (Africa only or international), its export dynamics (whether a firm entered ${ }^{4}$, exited ${ }^{5}$ or continued $^{6}$ in the export market), the number of products (on HS6-digit level) it exported and the number of destinations it served.

The dates of the three datasets were not aligned, as all three datasets worked on different reporting years/periods. Therefore, the final panel consisted of manufacturing firms and dates from the 2010 to the 2014 tax year (February 2009 to March 2014).

\subsection{Descriptive statistics on the employment premium and wage premium of exporters}

The descriptive statistics start with an overview of the data on the manufacturing sector to illustrate the number of non-exporters and exporters (exporting to different destinations). Table 1 shows that in 2011, for example, there were 32429 manufacturing firms, of which $21 \%$ (6868) were exporters. Of these, 4010 (12\%) firms exported to African countries only while 2858 (9\%) exported to international markets (both African and non-African countries). The total number of firms was lower in 2014 than in 2013 because (as mentioned earlier) some firms had not submitted the CIT forms for $2014 .^{7}$

Table 1: Number of manufacturing non-exporters and exporters (to different destinations)

\begin{tabular}{|c|c|c|c|c|c|}
\hline & 2010 & 2011 & 2012 & 2013 & 2014 \\
\hline Non-exporters & $\begin{array}{l}24959 \\
(83 \%)\end{array}$ & $\begin{array}{l}25561 \\
(79 \%)\end{array}$ & $\begin{array}{l}24868 \\
(78 \%)\end{array}$ & $\begin{array}{l}27256 \\
(77 \%)\end{array}$ & $\begin{array}{l}22992 \\
(76 \%)\end{array}$ \\
\hline $\begin{array}{l}\text { Exporters } \\
\text { - Africa only } \\
\text { - International }\end{array}$ & $\begin{array}{l}4957 \quad(17 \%) \\
2960 \\
(10 \%) \\
1997 \\
(7 \%)\end{array}$ & $\begin{array}{l}6868(21 \%) \\
4010 \\
(12 \%) \\
2858 \\
(9 \%)\end{array}$ & $\begin{array}{l}7145 \quad(22 \%) \\
4224 \\
(13 \%) \\
2921 \\
(9 \%)\end{array}$ & $\begin{array}{l}8117(23 \%) \\
4746 \\
(13 \%) \\
3371 \\
(10 \%)\end{array}$ & $\begin{array}{l}7257 \text { (24\%) } \\
4226 \\
(14 \%) \\
3031 \\
(10 \%)\end{array}$ \\
\hline $\begin{array}{l}\text { Total number } \\
\text { manufacturing firms (100\%) }\end{array}$ & $\begin{array}{l}29916 \\
(100 \%)\end{array}$ & $\begin{array}{l}32429 \\
(100 \%)\end{array}$ & $\begin{array}{l}32013 \\
(100 \%)\end{array}$ & $\begin{array}{l}35373 \\
(100 \%)\end{array}$ & $\begin{array}{l}30249 \\
(100 \%)\end{array}$ \\
\hline
\end{tabular}

\footnotetext{
3 The customs data only shows direct exports, therefore indirect exports are not captured by the data (this is a limitation faced by other similar studies).

4 Entering firms are firms that did not export in $\mathrm{t}-1$, but exported in $\mathrm{t}$.

${ }^{5}$ Exiting firms are firms that exported in $\mathrm{t}-1$, but not in year $\mathrm{t}$.

${ }^{6}$ Continuing firms are firms that exported in year $\mathrm{t}-1$ and $\mathrm{t}$.

7 As the total number of firms declined in 2014, all regressions (see section 4.3) were estimated with and without data for 2014 . The results excluding 2014 are available on request.
} 
Offering a broader perspective, Figure 1 shows the percentage of manufacturing exporters per destination category compared with the value of exports per destination category.

Figure 1 supports Table 1, showing that $59 \%$ of South Africa's manufacturing exporting firms exported to Africa only, but these firms exported only $11 \%$ of the total export value, during the period 2010-2014. Furthermore, 41\% of manufacturing exporting firms exported to the international market during the period in question, with these firms contributing $89 \%$ of the total export value.

\section{Percentage of manufacturing exporters per destination category}

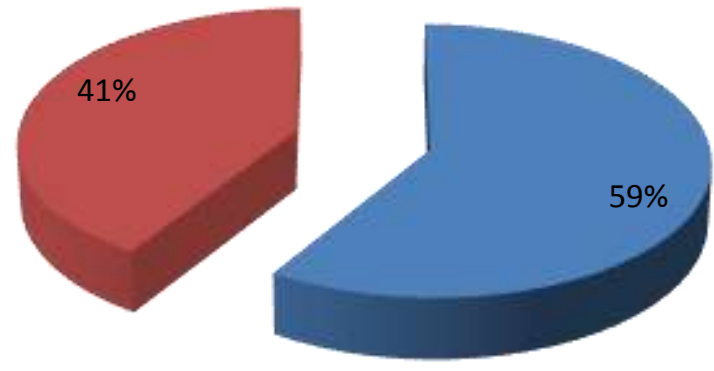

Africa only

- International

\section{Value of manufactured exports per destination category}

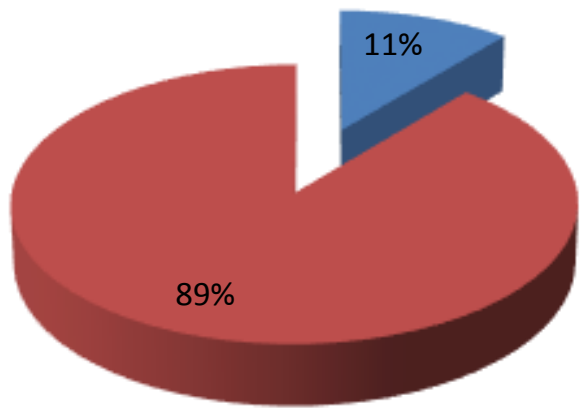

Africa only

- International

Figure 1: Percentage of manufacturing exporters, and average value of manufactured exports, per destination category (2010-2014)

Source: Authors' own calculations

Table 2 offers a detailed breakdown of the number of employees, wages per person and wages per exporting firm. It also distinguishes between exporters serving Africa only and those serving the international market.

Exporting firms employed, on average, four times more workers than non-exporting firms (82 versus 19). Those firms serving the international market employed the most workers and paid the highest wages (per person and per firm). The median figures provide a picture of a 'typical' exporter in each category. Thus, the international exporters were still the largest (in terms of employees) and paid the highest wages, followed by Africa-only exporters and then nonexporters. 
Table 2: Number of employees, wages per person and firm wages (averages for 2010-2014) ${ }^{8}$

\begin{tabular}{lccr}
\hline & Number of employees & $\begin{array}{c}\text { Annual wages per person } \\
\text { (ZAR) }\end{array}$ & $\begin{array}{c}\text { Annual firm wages } \\
\text { (ZAR) }\end{array}$ \\
\hline $\begin{array}{l}\text { Non-exporters } \\
\text { Mean }\end{array}$ & 19 & 201976 & 2116382 \\
$\quad$ Median & 7 & 96468 & 667673 \\
Exporters & & & \\
$\quad$ Mean & 82 & 262130 & 16260000 \\
$\quad$ Median & 20 & 144725 & 2771373 \\
- International & & & \\
$\quad$ Mean & 137 & 324834 & 31340000 \\
$\quad$ Median & 28 & 164132 & 4294574 \\
- Africa only & & & \\
$\quad$ Mean & 47 & 233918 & 6660803 \\
$\quad$ Median & 18 & 149071 & 2588920 \\
\hline
\end{tabular}

Source: Authors' own calculations

It is clear from Tables 1 and 2 that exporting and non-exporting firms differed from each other in terms of number of employees and wages, and that wage differences were also evident within exporting firms themselves (pointing to exporter heterogeneity). The employee number and wage differences might have been due to firms operating in different industries, and some firms having more capital or simply being larger. These results needed to be tested in terms of OLS regressions, using control variables. The regression results are provided in sections 4.3 and 4.4 below. Section 4.3 focuses on the employment premium and wage premium of exporters, while section 4.4 focuses on employment growth (that is, the types of jobs that are created through exporting).

\subsection{Regressions on the employment premium and wage premium of exporters}

To understand whether increasing export activity is one of the solutions to the high unemployment levels in South Africa this paper investigates the relationship between exporting, labour demand and wages at a firm-level in South Africa. Inorder to measure the firm characteristics (number of employees and wages) of exporting firms (relative to nonexporters as well as within-exporters this paper follows the recognised methodology of Bernard and Jensen (1995). The export premia and exporter heterogeneity for firm characteristics (number of employees and wages) were estimated by using regressions of the general form:

8 The number of employees and the wage figures were all weighted. 


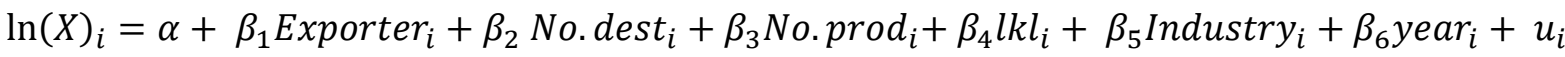

Where:

$X_{i}$ - In of firm characteristics (number of employees, wages per person, total wages (total labour cost))

Exporter $_{i}$ - Dummy variable of export status (exporter $=1$ and non-exporter $=0$ )

No. dest ${ }_{i}$ - Number of destinations a firm exports to (this is 0 if the firm does not export)

No. $\operatorname{prod}_{i}-$ Number of products exported by firm (this is 0 if the firm does not export)

$l k l_{i}-\ln$ capital per worker

Industry $y_{i}$ - Control dummy (4-digit ISIC classification) to account for heterogeneity

year $_{i}$ - Control dummy for the years 2010 to 2014

$\beta_{i}-$ Export premia

$\mu_{i t}-$ Error term

Sections 4.3.1 and 4.3.2 present the results of estimating equation 1 by showing the number of employees and average wages while distinguishing between different export destinations and export dynamics.

\subsubsection{Employment and wage premium of exporters serving different destinations}

Table 3 shows that exporting firms are larger (in terms of number of employees) ${ }^{9}$ and pay more (per person and in total) ${ }^{10}$ than non-exporting firms. Furthermore, the destination mattered $^{11}$, as an exporter exporting to African countries only was smaller than international exporters $^{12}$. African exporters (column 2) seemed to pay higher wages per person than their

$9 \quad$ As found by Bernard and Wagner (1997) and Brambilla et al. (2015).

10 As shown by, for example, Bernard et al. (2007), Isgut (2001), Schank et al. (2007), Fafchamps (2007), Brambilla et al. (2010), Amiti and Davis (2012), and Brambilla et al. (2015).

11 As seen in Alcalá and Hernández (2010), Serti et al. (2010), Rankin and Schöer (2013), Matthee et al. (2016b).

12 An analysis was done to see whether the high employment propensity of firms exporting to international markets relative to African markets were influenced by income level of the market (GDP 
international counterparts (column 5), but this is because the number of products and destinations were controlled for (since African firms exported fewer products to fewer destinations). If the product and destination control were removed (column 2), the international exporters would pay higher wages than African exporters.

Table 3: Employment and wage premium: exporters to destinations within and outside Africa

\begin{tabular}{|c|c|c|c|c|c|}
\hline $\begin{array}{l}\text { No. of } \\
\text { employees }\end{array}$ & $\begin{array}{l}\text { Wages } \\
\text { per } \\
\text { person }\end{array}$ & $\begin{array}{l}\text { Total } \\
\text { wages }\end{array}$ & $\begin{array}{l}\text { No. of } \\
\text { employee } \\
\text { s }\end{array}$ & $\begin{array}{l}\text { Wages } \\
\text { per } \\
\text { person }\end{array}$ & $\begin{array}{l}\text { Total } \\
\text { wages }\end{array}$ \\
\hline
\end{tabular}

(3)

(5)

(6)

\begin{tabular}{|c|c|c|c|c|c|c|}
\hline & & & & (4) & & \\
\hline \multirow[t]{2}{*}{ Export dummy } & $1.434^{\star \star \star}$ & $0.410^{\star \star \star}$ & $0.685^{\star \star \star}$ & $0.737^{\star \star \star}$ & $0.231^{\star \star \star}$ & $0.383^{\star \star *}$ \\
\hline & $(0.0127)$ & $(0.00897)$ & $(0.00905)$ & $(0.0161)$ & $(0.0116)$ & $(0.0112)$ \\
\hline \multirow[t]{2}{*}{ Africa only } & $-0.518^{\star * \star}$ & $-0.0864^{* * *}$ & $-0.185^{\star \star \star}$ & $-0.135^{\star * \star}$ & 0.00663 & $-0.0207^{*}$ \\
\hline & $(0.0174)$ & $(0.0124)$ & $(0.0119)$ & $(0.0183)$ & $(0.0132)$ & $(0.0126)$ \\
\hline Number of destinations & & & & $\begin{array}{l}0.0677^{\star \star \star} \\
(0.00135)\end{array}$ & $\begin{array}{l}0.0154^{* * *} \\
(0.000975 \\
)\end{array}$ & $\begin{array}{l}0.0297^{\star \star *} \\
(0.000942 \\
)\end{array}$ \\
\hline Number of products & & & & $\begin{array}{l}0.00435^{\star \star *} \\
(0.000177)\end{array}$ & $\begin{array}{l}0.00172^{* * *} \\
(0.000127 \\
)\end{array}$ & $\begin{array}{l}0.00263^{\star * *} \\
(0.000122 \\
)\end{array}$ \\
\hline$|k|$ & $\begin{array}{l}-0.0123^{* * *} \\
(0.00135)\end{array}$ & $\begin{array}{l}0.0583^{* * *} \\
(0.000959 \\
)\end{array}$ & $\begin{array}{l}0.0560^{* * *} \\
(0.000923 \\
)\end{array}$ & $\begin{array}{l}-0.0166^{\star \star *} \\
(0.00132)\end{array}$ & $\begin{array}{l}0.0572^{\star \star *} \\
(0.000957 \\
)\end{array}$ & $\begin{array}{l}0.0538^{* * *} \\
(0.000916 \\
)\end{array}$ \\
\hline Year control & Yes & Yes & Yes & Yes & Yes & Yes \\
\hline Industry controls & Yes & Yes & Yes & Yes & Yes & Yes \\
\hline Firm size control & & & Yes & & & Yes \\
\hline Observations & 130654 & 128189 & 128189 & 130654 & 128189 & 128189 \\
\hline
\end{tabular}

Note: Robust standard errors in parenthesis and ${ }^{* *} p<0.01 \quad{ }^{* *} p<0.05 \quad{ }^{*} p<0.1$ (Is significant at the $1 \%$ level, $5 \%$ level and 10\% level, respectively).

Source: Authors' own calculations.

As column 4 in Table 3 reports, the marginal effect when adding one destination (7\% more in terms of number of employees) is higher than when adding one product $(0.44 \%$ more in terms of number of employees). Therefore, it is clear that to simply increase export activity as a solution to high unemployment in South Africa is a too simplistic approach. Exporting firms are complex as they are heterogenous and their export premiums differ by destination served (African versus international exporters), number of products exported and number of destinations exported to. The exporter heterogeneity isfurther investigated by considering firms in different stages of exporting (export dynamics).

of export destination) as well as product sophistication (relative price per product), but the regression results were insignificant. 


\subsubsection{Employment and wage premium of exporters with different export dynamics}

Table 4 illustrates the employment levels and wages of exporters with different export dynamics, relative to non-exporters. Firms that entered and exited the export market were smaller (in terms of the number of employees) and paid less (per person [columns 2 and 5] and overall [columns 3 and 6]) than continuing firms. Therefore, continuing firms have the highest contribution to employment and wages. Interestingly, when controlling for the number of products and the number of destinations (column 2), the wage per person was $3.08 \%$ higher for entering firms than continuing firms. Without the control (column 5), the continuing firms paid a $3.9 \%$ higher wage per person. From this, it can be deduced that firms entering the export market exported fewer products (on average, 16 versus 25) to fewer destinations (on average, 4 versus 6 ) than continuing firms. Therefore, as firms continued to export, they grew in terms of the number of products exported and the number of destinations served.

Table 4: Employment and wage premium of exporters with different export dynamics (enter, exit and continue in the export market)

\begin{tabular}{|c|c|c|c|c|c|}
\hline $\begin{array}{l}\text { No. of } \\
\text { employees } \\
\text { (1) }\end{array}$ & $\begin{array}{l}\text { Wages } \\
\text { per } \\
\text { person }\end{array}$ & $\begin{array}{l}\text { Total } \\
\text { wages } \\
(3)\end{array}$ & $\begin{array}{l}\text { No. of } \\
\text { employees } \\
\text { (4) }\end{array}$ & $\begin{array}{l}\text { Wages per } \\
\text { person } \\
\text { (5) }\end{array}$ & (6) \\
\hline
\end{tabular}

(2)

\begin{tabular}{|c|c|c|c|c|c|c|}
\hline \multirow[t]{2}{*}{ Continue } & $1.239^{* * *}$ & $0.353^{\star \star \star}$ & $0.564^{\star * \star}$ & $0.735^{\star * *}$ & $0.198^{\star \star \star}$ & $0.340^{\star \star \star}$ \\
\hline & $(0.011)$ & $(0.0078)$ & $(0.00799)$ & $(0.0127)$ & $(0.00916)$ & $(0.00895)$ \\
\hline \multirow[t]{2}{*}{ Enter } & $0.759^{* * *}$ & $0.325^{\star * *}$ & $0.453^{* * *}$ & $0.428^{* * *}$ & $0.223^{* \star *}$ & $0.306^{\star \star \star}$ \\
\hline & $(0.0157)$ & $(0.0111)$ & $(0.0109)$ & $(0.0159)$ & $(0.0115)$ & $(0.0111)$ \\
\hline \multirow[t]{2}{*}{ Exit } & $0.539^{* * *}$ & $0.204^{* * *}$ & $0.295^{\star * *}$ & $0.419^{* * *}$ & $0.168^{* \star *}$ & $0.249^{\star \star \star}$ \\
\hline & $(0.0301)$ & $(0.0212)$ & $(0.0206)$ & $(0.0294)$ & $(0.0212)$ & $(0.0204)$ \\
\hline \multirow[t]{2}{*}{$\mid \mathrm{kl}$} & $-0.00651^{\star * \star}$ & $0.0574^{\star * \star}$ & $0.0564^{\star \star *}$ & $-0.0133^{* * *}$ & $0.0554^{* \star *}$ & $0.0528^{* * *}$ \\
\hline & $(0.00147)$ & $(0.00104)$ & $(0.00101)$ & $(0.00143)$ & $(0.00104)$ & $(0.001)$ \\
\hline No. dest \& prod control & No & No & No & Yes & Yes & Yes \\
\hline Year control & Yes & Yes & Yes & Yes & Yes & Yes \\
\hline Industry controls & Yes & Yes & Yes & Yes & Yes & Yes \\
\hline Firm size control & & & Yes & & & Yes \\
\hline Observations & 108546 & 106680 & 106680 & 108546 & 106680 & 106680 \\
\hline
\end{tabular}

Note: Robust standard errors in parenthesis and ${ }^{* *} p<0.01 \quad{ }^{* *} p<0.05 \quad{ }^{*} p<0.1$ (Is significant at the $1 \%$ level, $5 \%$ level and $10 \%$ level respectively.)

Source: Authors' own calculations.

Expanding on Table 4, Figure 2 investigates the exporter heterogeneity further by providing a graphical illustration of the regression results and adding destination categories to the export dynamics. Furthermore, total wages are displayed as the combination of the number of employees and wages per employee. From Figure 2, it is clear that, when considering the 
differences between domestic-oriented firms and those that enter, exit or continue in the export market, the export destination (Africa only market or international market) does matter.

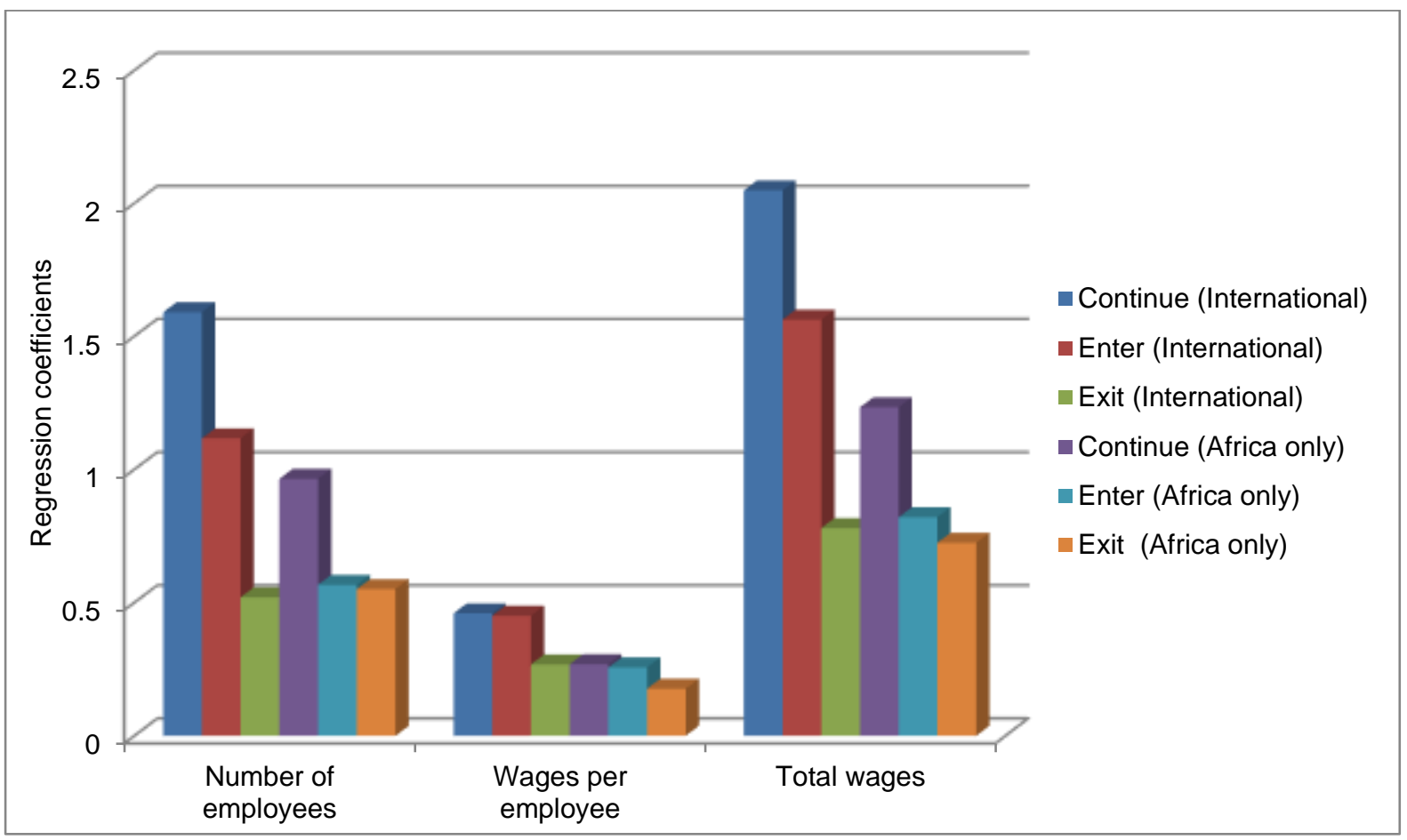

Figure 2: Coefficients of the employment and wage premium: non-exporters versus exporters (exporting to African and non-African countries)

Note: Premium relative to non-exporters

Source: Authors' own calculations

In terms of size (number of employees), firms continuing to export in the international market were the largest, followed by firms entering the international market, firms continuing in the African market, firms entering the African market, firms exiting the African market and firms exiting the international market. Overall, when comparing the international-type firms with the Africa only-type firms in terms of firm size, wage per employee and total labour cost (total wages), the international-type firms showed superior characteristics to the Africa only-type firms. This is in line with the results in Table 4 showing that international exporters were larger and paid more (alluding to the hierarchy that exists when export destinations are further away). There appears to be a sort of threshold, i.e. firms on average need to be larger (relative to non-exporters) to enter the export market, but entrants may grow over time since they are smaller than continuous exporters. An alternative explanation is that, in the past, firms were larger when they entered the export market, but recent entrants have, for some reason, been smaller. In order to unravel these phenomena, such firms need to be tracked over a period of time. 
When considering exporter heterogeineity while searching for a possible solution to high unemployment levels in South Africa, it is clear that the type of exporter with the highest number of employees is firms either continuing or entering the international market.

When considering wages (from figure 2), it is clear that wages did not appear to grow as a result of exporting. The wage per employee of firms entering the export market was already high compared to that of continuing firms; this applied to African as well as international firms. This suggests that firms that entered the export market were relatively large (compared to non-exporters). If the difference in size between entrants and continuous exporters can be interpreted as employment growth, then because average wages were the same, entrants added similar types of workers to those who were working there previously (i.e. the distribution of wages did not change; the number just rose). The fact that entering firms already paid higher wages (relative to non-exporters) is in line with the findings of Isgut (2001) who revealed that even before a firm starts exporting, it displays superior characteristics.

From figure 2 it is clear that overall, exporting firms employ more workers and pay higher wages. The question that arises iswhat type of jobs are they growing? Section 4.4 focuses on the employment growth of exporters. Not only does this measure explain growth in employment, but it also distinguishes between the different types of employees being employed when a firm exports.

\subsection{Regressions on employment growth}

From section 4.3 it is clear that to simply increase export activity as a way to create employment in South Africa is too simplistic approach. Exporting firms are heterogenous in that export premiums differ by destination served (African versus international exporters), number of products exported and number of destinations exported. This section goes further by considering the types of jobs these heterogeneous exporters grow.

Employment growth among exporters can be achieved through exporters entering the export market (extensive margin) or continuing to export (intensive margin). This section considers employment growth of exporters (relative to non-exporters) in the light of both the extensive and intensive margins.

Inorder to measure employment growth, this paper follows Biscourp and Kramarz (2007:34) by estimating a first-difference regression of the general form:

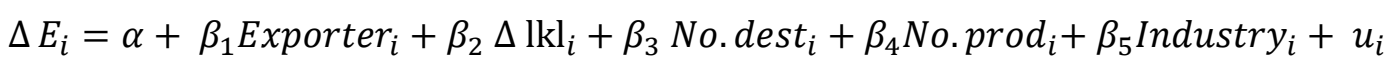


In equation 2, $\Delta E_{i}$ was the growth in employment over the sample period 2010-2013 ${ }^{13}$. The growth was calculated by taking the logged number of employees in 2013 and subtracting the logged number of employees in 2010. The (overall) growth of all employees in a firm was first measured. Then, to differentiate between the employment growth of different types of workers, the growth in the number of employees above and below 30 years of age and employees earning above and below $\mathrm{R} 6500$ per month was also measured ${ }^{14}$.

The 'Exporter ${ }_{i}$ ' is a dummy variable indicating the export status of a firm, ranging from a nonexporter to an exporter serving either the African or international market. The export status also includes firm dynamics (enter, exit or continue). Continuing exporters are firms that exported in all four years (2010-2013), entrants are firms that did not export in 2010, but exported in 2013, and exiting exporters are firms that did export in 2010, but not in 2013. Finally, the equation includes a number of control variables: growth in capital $(\Delta \mathrm{lkl})$, the number of destinations exported to by a firm $\left(N_{o}\right.$. dest $\left._{i}\right)$, the number of products exported by

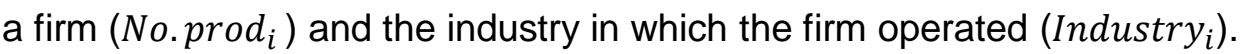

The results of the estimation of equation 2 are presented in Tables 5 to 7 . Besides revealing the growth in overall employment, the tables also decompose the growth into different types of jobs (employment growth of workers aged above and below 30 , and workers earning above and below R6500 per month) (SARS, 2017).

Table 5 provides an overall picture of the employment growth of international exporters and Africa only exporters relative to non-exporters. Column 1 shows that even though international exporters were growing their employment faster than Africa only exporters, both of these exporting groups grew their employment faster than non-exporters.

For international exporters, the growth in employment of workers above the age of 30 years was almost $10 \%$ higher than that of workers under the age of 30 (columns 2 and 3 ). This suggests that exporters grew their employment by hiring more experienced workers (if age is used as an indication of experience). The growth in employment of people earning more than R6500 per month was $35 \%$ higher than that of people earning below R6500 per month, which confirms that when exporters grow their employment, they hire more skilled/better-qualified workers (if income is used as an indication for skills/qualification). For Africa-only exporters,

13 To calculate employment growth without short-term fluctuations, the period 2010-2013 was used. As 2014 had fewer observations in the data, it was excluded from these regressions.

14 As there were no variables on education, skills and experience of workers, this study used age (above and below 30) and income (earning above and below R6500) as indications of skills and experience. 
column 5 shows growth in the employment of people earning above R6500; however, the growth in employment of people earning below R6500 per month was not significantly more than that for non-exporters.

Table 5: Employment growth: exporters to African and non-African countries

\begin{tabular}{|c|c|c|c|c|c|}
\hline & $\begin{array}{l}\Delta \text { No. of } \\
\text { employees } \\
\text { (1) }\end{array}$ & $\begin{array}{l}\Delta \text { below age } \\
\text { of } 30 \\
(2)\end{array}$ & $\begin{array}{l}\Delta \text { above age } \\
\text { of } 30 \\
\text { (3) }\end{array}$ & $\begin{array}{l}\Delta \text { below } \\
\text { R6500 pm } \\
\text { (4) }\end{array}$ & $\begin{array}{l}\Delta \text { above } \\
\text { R6500 pm } \\
\text { (5) }\end{array}$ \\
\hline \multirow[t]{2}{*}{ Export dummy } & $0.212^{* \star \star}$ & $0.157^{\star \star \star}$ & $0.251^{* \star \star}$ & $0.0583^{*}$ & $0.408^{\star \star \star}$ \\
\hline & $(0.0301)$ & $(0.0288)$ & $(0.0297)$ & $(0.0322)$ & $(0.0265)$ \\
\hline \multirow[t]{2}{*}{ Africa only } & $-0.143^{\star * *}$ & $-0.116^{* * *}$ & $-0.165^{\star \star \star}$ & -0.0440 & $-0.196^{\star * \star}$ \\
\hline & $(0.0312)$ & $(0.0298)$ & $(0.0308)$ & $(0.0334)$ & $(0.0275)$ \\
\hline \multirow[t]{2}{*}{$\Delta \mid \mathrm{kl}$} & $0.150^{\star \star \star}$ & $0.102^{* * *}$ & $0.143^{* \star *}$ & $0.136^{\star \star \star}$ & $0.0958^{\star \star \star}$ \\
\hline & $(0.00111)$ & $(0.00106)$ & $(0.00109)$ & $(0.00119)$ & $(0.000974)$ \\
\hline No. dest \&prod control & Yes & Yes & Yes & Yes & Yes \\
\hline Year control & Yes & Yes & Yes & Yes & Yes \\
\hline Industry controls & Yes & Yes & Yes & Yes & Yes \\
\hline Observations & 31961 & 31961 & 31961 & 31961 & 31961 \\
\hline
\end{tabular}

Note: Robust standard errors in parenthesis and ${ }^{* *} p<0.01{ }^{* *} p<0.05 \quad{ }^{*} p<0.1$ (Is significant at the $1 \%$ level, $5 \%$ level and $10 \%$ level, respectively).

Source: Authors' own calculations

When considering the premise that increasing export activity is one of the solutions to high unemployment levels in South Africa, it is important to note that even though the growth in employment was skewed towards older (more experienced), higher-skilled workers, the growth in employment of younger, lower-skilled workers was still higher than that of nonexporters. This suggests that exporters (relative to non-exporters) also create jobs for younger workers with fewer skills (though not as rapidly as for older workers with more skills).

Table 6 shows the types of jobs (young/old or low/highly paid) which were added or lost by exporters entering the export market (extensive margin) or continuing to export (intensive margin). Firms that entered the export market (extensive margin) between 2010 and 2013 showed the largest growth in total employment (58\%). These firms displayed higher growth in the employment of more experienced (column 2 versus column 3 ) and higher-skilled (column 4 versus column 5) workers. When firms exited the export market, their employment growth was negative relative to non-exporting firms. This could be due to these firms not only exiting the export market, but also exiting the domestic market (closing down). 
Table 6: Employment growth: export dynamics

\begin{tabular}{|c|c|c|c|c|c|}
\hline & $\begin{array}{l}\Delta \text { No. of } \\
\text { employees } \\
(1)\end{array}$ & $\begin{array}{l}\Delta \text { below age } \\
\text { of } 30 \\
(2)\end{array}$ & $\begin{array}{l}\Delta \text { above age } \\
\text { of } 30 \\
(3)\end{array}$ & $\begin{array}{l}\Delta \text { below } \\
\text { R6500 pm } \\
(4)\end{array}$ & $\begin{array}{l}\Delta \text { above } \\
\text { R6500 pm } \\
\text { (5) }\end{array}$ \\
\hline Continue & $\begin{array}{l}-0.0531^{* *} \\
(0.0292)\end{array}$ & $\begin{array}{l}-0.0123^{* *} \\
(0.0282)\end{array}$ & $\begin{array}{l}-0.0051^{\text {***}} \\
(0.0287)\end{array}$ & $\begin{array}{l}-0.131^{* * *} \\
(0.0316)\end{array}$ & $\begin{array}{l}0.185^{\star \star \star} \\
(0.0255)\end{array}$ \\
\hline Exit & $\begin{array}{l}-0.385^{\star \star \star} \\
(0.0210)\end{array}$ & $\begin{array}{l}-0.208^{* *} \\
(0.0203)\end{array}$ & $\begin{array}{l}-0.335^{\star \star \star} \\
(0.0207)\end{array}$ & $\begin{array}{l}-0.425^{\star * \star} \\
(0.0228)\end{array}$ & $\begin{array}{l}-0.12205^{\star * *} \\
(0.0184)\end{array}$ \\
\hline Enter & $\begin{array}{l}0.579 * * * \\
(0.0431)\end{array}$ & $\begin{array}{l}0.365^{\star * *} \\
(0.0416)\end{array}$ & $\begin{array}{l}0.575^{\star * *} \\
(0.0424)\end{array}$ & $\begin{array}{l}0.334^{* * *} \\
(0.0467)\end{array}$ & $\begin{array}{l}0.739 * * * \\
(0.0377)\end{array}$ \\
\hline$\Delta \mathrm{lkl}$ & $\begin{array}{l}0.148^{\star \star *} \\
(0.00112)\end{array}$ & $\begin{array}{l}0.102^{\star \star \star} \\
(0.00109)\end{array}$ & $\begin{array}{l}0.141^{* * *} \\
(0.00111)\end{array}$ & $\begin{array}{l}0.135^{\star \star \star} \\
(0.00122)\end{array}$ & $\begin{array}{l}0.094^{* * *} \\
(0.000983)\end{array}$ \\
\hline No. dest \&prod control & Yes & Yes & Yes & Yes & Yes \\
\hline Year control & Yes & Yes & Yes & Yes & Yes \\
\hline Industry controls & Yes & Yes & Yes & Yes & Yes \\
\hline Observations & 31961 & 31961 & 31961 & 31961 & 31961 \\
\hline
\end{tabular}

Note: Robust standard errors in parenthesis and ${ }^{* * *} p<0.01 \quad{ }^{* *} p<0.05 \quad{ }^{*} p<0.1$ (Is significant at the $1 \%$ level, $5 \%$ level and $10 \%$ level, respectively).

Source: Authors' own calculations

Table 7: Employment growth: export dynamics to African and non-African countries

\begin{tabular}{|c|c|c|c|c|c|}
\hline & $\begin{array}{l}\Delta \text { No. of } \\
\text { employees } \\
\text { (1) }\end{array}$ & $\begin{array}{l}\Delta \text { below age } \\
\text { of } 30 \\
(2)\end{array}$ & $\begin{array}{l}\Delta \text { above age } \\
\text { of } 30 \\
(3)\end{array}$ & $\begin{array}{l}\Delta \text { below } \\
\text { R6 } 500 \text { pm } \\
\text { (4) }\end{array}$ & $\begin{array}{l}\Delta \text { above } \\
\text { R6 } 500 \text { pm } \\
\text { (5) }\end{array}$ \\
\hline \multirow{2}{*}{ Continue (international) } & $0.0397^{*}$ & $0.0592^{*}$ & $0.110^{\star * \star}$ & $-0.0856^{\star *}$ & $0.304^{\star \star \star}$ \\
\hline & $(0.0348)$ & $(0.0333)$ & $(0.0343)$ & $(0.0373)$ & $(0.0306)$ \\
\hline \multirow[t]{2}{*}{ Continue (Africa only) } & $-0.146^{\star * \star}$ & $-0.0838^{\star * *}$ & $-0.120^{\star \star \star}$ & $-0.176^{\star \star *}$ & $0.0649^{* * *}$ \\
\hline & $(0.0264)$ & $(0.0252)$ & $(0.0260)$ & $(0.0283)$ & $(0.0232)$ \\
\hline \multirow[t]{2}{*}{ Exit (international) } & $-0.287^{\star \star \star}$ & -0.0825 & $-0.234^{\star *}$ & $-0.384^{\star \star \star}$ & -0.0221 \\
\hline & $(0.103)$ & $(0.0989)$ & $(0.102)$ & $(0.111)$ & $(0.0910)$ \\
\hline \multirow{2}{*}{ Exit (Africa only) } & $-0.483^{\star * *}$ & $-0.333^{\star * *}$ & $-0.436^{\star * *}$ & $-0.466^{\star * *}$ & $-0.222^{* * *}$ \\
\hline & $(0.0667)$ & $(0.0639)$ & $(0.0658)$ & $(0.0715)$ & $(0.0588)$ \\
\hline \multirow{2}{*}{ Enter (international) } & $0.426^{\star * *}$ & $0.276^{\star * *}$ & $0.416^{\star * *}$ & $0.224^{\star * *}$ & $0.547^{* * *}$ \\
\hline & $(0.0425)$ & $(0.0407)$ & $(0.0420)$ & $(0.0456)$ & $(0.0374)$ \\
\hline \multirow{2}{*}{ Enter (Africa only) } & $0.305^{\star * *}$ & $0.177^{\star \star \star}$ & $0.318^{* * *}$ & $0.220^{\star * *}$ & $0.384^{\star \star \star}$ \\
\hline & $(0.0298)$ & $(0.0285)$ & $(0.0294)$ & $(0.0320)$ & $(0.0263)$ \\
\hline \multirow{2}{*}{$\Delta \mathrm{lkl}$} & $0.147^{* \star *}$ & $0.100^{\star * *}$ & $0.140^{\star * *}$ & $0.133^{\star * \star}$ & $0.0939^{* \star *}$ \\
\hline & $(0.00112)$ & $(0.00107)$ & $(0.00110)$ & $(0.00120)$ & $(0.000985)$ \\
\hline No. dest \&prod control & Yes & Yes & Yes & Yes & Yes \\
\hline Year control & Yes & Yes & Yes & Yes & Yes \\
\hline Industry controls & Yes & Yes & Yes & Yes & Yes \\
\hline Observations & 31961 & 31961 & 31961 & 31961 & 31961 \\
\hline
\end{tabular}

Note: Robust standard errors in parenthesis and ${ }^{* * *} p<0.01{ }^{* *} p<0.05{ }^{*} p<0.1$ (Is significant at the $1 \%$ level, $5 \%$ level and $10 \%$ level respectively.

Source: Authors' own calculations 
Overall, the continuing exporting firms (intensive margin) seemed to grow their employment at a slightly slower rate (5\%) than non-exporting firms. Possibly these continuing exporting firms already had 'enough' workers or the capital (rather than labour) intensity in these firms was increasing. In columns 4 and 5, continuing exporters (relative to non-exporting firms) seemed to show lower growth in unskilled jobs (negative employment growth of $13 \%$ for workers earning below R6500 per month) and faster growth in skilled jobs (positive employment growth of $18.5 \%$ for workers earning above R6500 per month).

The slower growth in overall employment among continuing exporting firms ( $5 \%$ slower than non-exporters, as shown in column 1) might also have been influenced by the destination served. Table 7 therefore combines export dynamics with destinations served.

When distinguishing between the destination (Africa only or international) of the intensive margin (continuing firms), international firms had a 4\% (column 1) higher growth rate than nonexporting firms. Firms continuing to export to the African market showed a negative employment growth rate relative to non-exporters, as did exiting firms (column 1). It was the firms entering the international market that demonstrated the highest growth rate in employment, followed by firms entering the Africa-only market. ${ }^{15}$

Interestingly, even after distinguishing between continuing firms serving different destinations (Africa only or international), there was still slower growth, for both international and African exporters, in 'unskilled' jobs paying less than R6500 per month and more rapid growth in 'skilled' jobs paying more than R6500 per month, relative to non-exporters. Therefore, one needs to keep in mind that the high unemployment levels of South Africa can be lessened with export activity, but the type jobs that are created by exporting firms are skewed towards more skilled workers.

\section{Key conclusions}

Export activity is viewed globally as a stimulant to higher firm-level productivity and stronger employment and economic growth in a country. In South Africa, policymakers have long acknowledged the important link between stronger exports and more sustainable job creation and economic growth. Yet the South African literature on the relationship between exporting, employment and wages is limited, especially on the firm level. The empirical study presented

15 Owing to data availability problems, the estimations were for the period 2010-2013 only. The shortterm, year-on-year estimations were inconsistent (probably due to the presence of occasional exporters). 
in this paper, which set out to address current gaps in the literature, by investigating if increasing export activity is one of the solutions to high unemployment levels in South Africa

In line with many global studies, it was found that South African exporters in the manufacturing sector employ more workers and pay higher wages than non-exporters, giving rise to an employment premium and a wage premium. In other words, the export sector creates more (and better-paying) jobs. Within exporting firms, though, the actual export premium and wage premium are linked to factors such as the size of the firm, the number of products exported, the destinations served and export 'dynamics' relating to whether a firm is entering a foreign market for the first time, continuing in the market or exiting the market.

Another important finding was that firms exporting to the international market (both African and non-African countries) employ more workers and pay higher wages than those exporting to African countries only. In addition, the former make a greater contribution to the manufacturing sector in terms of total export value than the latter. Interestingly, firms that enter the export market for the first time (be it Africa-only or international markets) do not then start to pay higher wages. They are already paying relatively high wages - at similar levels to firms that are continuing in the export market. This suggests that in order to be competitive enough to embark on an export drive, new entrants need workers with particular skill sets, which command higher wages.

Overall, exporting firms showed faster employment growth than non-exporting firms, with such growth more evident among higher-skilled (earning above R6500) and more experienced (older than 30 years) workers. Among exporters, the fastest employment growth rate was recorded in the extensive margin (firms entering the export market). In the intensive margin (firms continuing to export) there was faster growth in 'skilled jobs' than in 'unskilled jobs'. Exporters to international markets (where the largest proportion of high-value export opportunities lie) demonstrated more rapid employment growth than exporters to African countries only and non-exporters.

The study that gave rise to this paper revealed that employment and wages - both major concerns of government, business and ordinary citizens - need to be properly understood if they are to assist policymaking and planning processes. In South Africa, simply encouraging more export activity as an antidote to high levels of unemployment is too simplistic a response. Exporters, after all, operate under very different circumstances and therefore a more tactical approach is needed. For example, helping exporters to make inroads into the international market would contribute most to sustainable employment creation in South Africa because, according to the results of this paper, exporters to the international market employ the most 
workers and pay the highest wages (relative to non-exporters). Africa-only exporters register lower employment and wage premiums (again, relative to non-exporters). Even if the exportrelated job pool were to start to expand, an ongoing challenge will be how to accommodate younger, less-skilled workers who are often casualties of South Africa's dysfunctional public education system.

The results of this paper provide a natural springboard into other areas of firm-level research. For example, as the dataset used did not have specific variables on workers' education, skills and experience, a qualitative analysis could be conducted of the specific characteristics of individuals employed by exporting firms. In addition, employment growth could be determined for more extended periods, which could provide informative yardsticks for policymakers.

\section{References}

Alcalá, F. \& Hernández, P.J. 2010. Firms' main market, human capital, and wages. SERIEs, 1(4):433-58.

Amiti, M. \& Davis, D.R. 2012. Trade, firms, and wages: Theory and evidence. The Review of Economic Studies, 79(1):1-36.

Aw, B.Y., Roberts, M.J. \& Yi Xu, D. 2011. R\&D investment, exporting, and productivity dynamics. The American Economic Review, 101(4):1312-44.

Bas, M. 2012. Technology adoption, export status, and skill upgrading: theory and evidence. Review of International Economics, 20(2):315-31.

Baumgarten, D. 2013. Exporters and the rise in wage inequality: evidence from German linked employer-employee data. Journal of International Economics, 90(1):201-17.Bernard, A.B. \& Wagener, J. 1997. Exports and success in German manufacturing. Weltwirtschaftliches Archiv, 133(1):134-57.

Bernard, A. \& Jensen, B. 1995. Exporters, Jobs, and Wages in U.S. Manufacturing: 19761987. Brookings Papers on Economic Activity. Microeconomics, 67-119.

Bernard, A.B. \& Jensen, J.B. 1997. Exporters, skill upgrading, and the wage gap. Journal of International Economics, 42(1):3-31.

Bernard, A.B. \& Jensen, J.B. 1999. Exceptional exporter performance: cause, effect, or both? Journal of International Economics, 47(1):1-25. 
Bernard, A.B., Jensen, J.B., Redding, S.J. \& Schott, P.K. 2007. Firms in international trade. The Journal of Economic Perspectives, 21 (3):105-30.

Bernard, A.B., Jensen, J.B. \& Schott, P.K. 2009. Importers, exporters and multinationals: a portrait of firms in the US that trade goods. In Producer dynamics: New evidence from micro data (pp. 513-552). University of Chicago Press. Cambridge, MA: National Bureau of Economic Research.

Bernard, A.B. \& Jensen, J.B. 1997. Exporters, skill upgrading, and the wage gap. Journal of international Economics, 42(1):3-31.

Bigsten, A., Collier, P., Dercon, S., Fafchamps, M., Gauthier, B., Willem Gunning, J., Oduro, A., Oostendorp, R., Pattillo, C., Söderbom, M. \& Teal, F. 2004. Do African manufacturing firms learn from exporting? Journal of development studies, 40(3):115-41.

Biscourp, P. \& Kramarz, F. 2007. Employment, skill structure and international trade: firmlevel evidence for France. Journal of International Economics, 72(1):22-51.

Brambilla, I., Carneiro, R.D. , Lederman, D. \& Porto, G. 2010. Skills, exports, and the wages of five million Latin American workers. http://elibrary.worldbank.org/doi/abs/10.1596/18139450-5246 Date of access: 5 Aug. 2016.

Brambilla, I., Chauvin, N.D. \& Porto, G. 2015. Wage and employment gains from exports: evidence from developing countries. CEPII Working Paper no 2015-28 - December. http://www.cepii.fr/PDF_PUB/wp/2015/wp2015-28.pdf Date of access: 19 Jan. 2017.

Cruz, A., Newman, C., Rand, J. \& Tarp, F. 2016. Learning by exporting: The case of Mozambican manufacturing. Journal of African Economies, 26(1):93-118.

Delgado, M.A., Farinas, J.C. \& Ruano, S. 2002. Firm productivity and export markets: a nonparametric approach. Journal of International Economics, 57(2):397-422.

Edwards, L., Rankin, N. \& Schöer, V. 2008. South African exporting firms: What do we know and what should we know? Journal of Development Perspectives, 4(1):67-92.

Edwards, L., Sanfilippo, M. \& Sundaram, A. 2016. Importing and firm performance: New evidence from South Africa (No. 2016/39). WIDER Working Paper.

Fafchamps, M. 2007. Human capital, exports, and wages. Economic and social research council (ESRC). Global poverty research group (GPRG). 
Fariñas, J.C. \& Martín-Marcos, A. 2007. Exporting and economic performance: firm-level evidence of Spanish manufacturing. The World Economy, 30(4):618-46.

Fernandes, A.M. \& Isgut, A.E. 2015. Learning-by-Exporting Effects: Are They for Real?. Emerging Markets Finance and Trade, 51(1):65-89.

Girma, S., Greenaway, A. \& Kneller, R. 2004. Does exporting increase productivity? A microeconometric analysis of matched firms. Review of International Economics, 12(5):85566.

Gumede, V. 2004. Export propensities and intensities of small and medium manufacturing enterprises in South Africa. Small Business Economics, 22(5):379-89.

Gumede, V. \& Rasmussen, V. 2002. Small manufacturing enterprises and exporting in South Africa: a preliminary assessment of key export success factors. Journal of Small Business and Enterprise Development, 9(2):162-71.

Hessels, J. \& Parker, S.C. 2013. Constraints, internationalization and growth: a crosscountry analysis of European SMEs. Journal of World Business, 48(1):137-48.

Isgut, A. 2001. What's different about exporters? Evidence from Colombian manufacturing. Journal of Development Studies, 37(5):57-82.

Klein, M.W., Moser, C. \& Urban, D.M. 2013. Exporting, skills and wage inequality. Labour Economics, 25:76-85.

Matthee, M. \& Krugell, W.F. 2012. Barriers to internationalisation: firm-level evidence from South Africa. Studia UBB Oeconomica, 57(1):3-20.

Matthee, M., Farole, T., Naughtin, T. \& Rankin, N. 2016a. South African exporters and the global crisis: intensive margin shock, extensive margin hangover. South African Journal of Economics, 84(2):183-98.

Matthee, M., Rankin, N., Naughtin, T. \& Bezuidenhout, C. 2016b. The South African manufacturing exporter story (No. 2016/38). WIDER Working Paper.

Melitz, M. 2003. The impact of trade on intra-industry reallocations and aggregate industry productivity. Econometrica, 71(6):1695-725. 
Milner, C. \& Tandrayen, V. 2007. The impact of exporting and export destination on manufacturing wages: evidence for Sub-Saharan Africa. Review of Development Economics, 11(1):13-30.

National Planning Commission. 2013. National development plan vision 2030.

Naughtin, T. \& Rankin, N. A. 2014. South African super-exporters: Are they different and what does this mean for policy? http://www.tips.org.za/research-archive/manufacturingconference-2014/item/2798-south-african-super-exporters-are-they-different-and-what-doesthis-mean-for-policy Date of access: 14 Feb. 2017.

Rankin, N. 2001. The export behaviour of South African manufacturing firms. Munich Personal RePEc Archive paper No 16904. https://mpra.ub.unimuenchen.de/16904/1/MPRA_paper_16904.pdf Date of access: 14 Feb. 2017.

Rankin, N.A. 2005. The determinants of manufacturing exports from Sub-Saharan Africa University of Oxford. (Thesis - PhD).

Rankin, N. 2013. Exporting and export dynamics among South African firms. South African Institute of International Affairs (SAIIA): Occasional Paper No 149, June 2013.

Rankin, N. \& Schöer, V. 2013. Export destination, product quality and wages in a middleincome country: the case of South Africa. Review of Development Economics, 17(1):64-73.

Rankin, N.A., Söderbom, M. \& Teal, F. 2006. Exporting from manufacturing firms in subSaharan Africa. Journal of African Economies, 15(4):671-87.

SARS. 2017. South African Revenue Services: Employment Tax Incentive (ETI) http://www.sars.gov.za/TaxTypes/PAYE/ETI/Pages/default.aspx Date of access: 27 March 2017.

Schank, T., Schnabel, C. \& Wagner, J. 2007. Do exporters really pay higher wages? First evidence from German linked employer-employee data. Journal of International Economics, 72(1):52-74.

Serti, F., Tomasi, C. \& Zanfei, A. 2010. Who trades with whom? Exploring the links between firms' international activities, skills, and wages. Review of International Economics, 18(5):951-71.

Siba, E. \& Gebreeyesus, M. 2016. Learning to export and learning from exporting: The case of Ethiopian manufacturing. Journal of African Economies,1-23. 
Sinani, E. \& Hobdari, B. 2010. Export market participation with sunk costs and firm heterogeneity. Applied Economics, 42(25):3195-207.

Statistics South Africa. 2017. Quarterly Labour Force Survey http://www.statssa.gov.za/publications/P0211/P02112ndQuarter2018.pdf Date of access 11 Oct 2018.

Turco, A.L. \& Maggioni, D. 2013. Does trade foster employment growth in emerging markets? Evidence from Turkey. World Development, 52:1-18.

Van Biesebroeck, J. 2005. Exporting raises productivity in sub-Saharan African manufacturing firms. Journal of International Economics, 67(2):373-91.

World Bank. 2014. South Africa economic update: focus on export competitiveness. South Africa economic update, issue no. 5, World Bank Group: Washington, DC. 